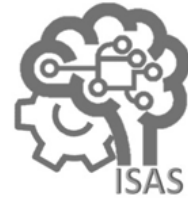

JOURNAL OF APPLIED CIVIL ENGINEERING AND INFRASTRUCTURE TECHNOLOGY (JACEIT)

\author{
Vol. 2 No. 2 (2021) 14-22 \\ ISSN Media Elektronik: 2723-5378
}

\title{
Analisis Perencanaan Sheet Pile pada Tanggul Sungai (Studi Kasus : Sungai Lungun, Sabanar Baru, Kabupaten Bulungan)
}

\author{
Hasrullah $^{1}$, Sebanya Elia ${ }^{2}$, Dandung Novianto ${ }^{3}$ \\ ${ }^{1,2}$ Jurusan Teknik Sipil, Fakultas Teknik Universitas Borneo Tarakan, \\ ${ }^{3}$ Jurusan Teknik Sipil,Fakultas Teknik Politeknik Negeri Malang \\ ${ }^{1}$ hasrullah.ray@borneo.ac.id, ${ }^{2}$ sebanya26@gmail.com, ${ }^{3}$ dandung.novianto@polinema.ac.id
}

\begin{abstract}
This study was conducted to identify thecauses of landslides on river embankments. This studu aims to determine the value of the slope safety factor and to plan the dimensions of sheet pile reinforcement and stability on the slopes of the Lungun River. This study used the Fellenius method to analyze the stability of the existing slope, the design principle of sheet piles in anchors located on cohesive soil with the free end method, and also with the help of a computer technology program, namely Plaxis application program. From the results of the analysis and calculations, it was concluded that the value of the safety factor on the slopes of the Lungun River using the manual calculations of the Fellinus Method. A value of 1.470 was obtained and a calculation using the Plaxis 2D V.8.2 program obtained a value of 1.1092. For the solutions to landslides on the slopes of the Lungun River, the dimensions of sheet pile reinforcement obtained from the calculation were using a concrete sheet pile type W-400 A 1000 with a depth of $10 \mathrm{~m}$ plus anchor recognition at a depth of $1 \mathrm{~m}$ from the ground surfaces which was connected by a steel tie rod $7 \mathrm{~cm}$ along $14 \mathrm{~m}$ to a concrete anchor block with height of $1.5 \mathrm{~m}$ and thickness of $5 \mathrm{~cm}$ which was embedded $0.5 \mathrm{~m}$ from the ground surface, so that the value of safety factor that was calculated using the Plaxis 2D V.8.2 program was 3.5814 .
\end{abstract}

Keywords: landslide, Plaxis program, sheet pile, slope stability, Lungun river

\begin{abstract}
Abstrak
Penelitian ini dilakukan untuk mengidentifikasi penyebab longsor pada tanggul sungai. Penelitian ini bertujuan untuk mengetahui nilai faktor keamanan lereng serta merencanakan dimensional perkuatan sheet pile dan stabilitas di lereng Sungai Lungun. Pada proses analisis data, peneliti menggunakan Metode Fellenius untuk menganalisa stabilitas lereng eksisting, prinsip perancangan turap di angker yang terletak pada tanah kohesif dengan metode ujung bebas, dan juga dengan bantuan program teknologi komputer yaitu program aplikasi Plaxis. Dari hasil analisis dan perhitungan, diperoleh kesimpulan bahwa nilai faktor keamanan pada lereng Sungai Lungun dengan menggunakan perhitungan manual Metode Fellenius diperoleh nilai sebesar 1,470 sedangkan hasil perhitungan dengan menggunakan program bantu Plaxis 2D V.8.2 didapatkan nilai factor keamanan sebesar 1,1092. Untuk solusi penanggulangan longsor lereng Sungai Lungun, ukuran dimensi perkuatan sheet pile yang diperoleh dari perhitungan yaitu menggunakan sheet pile beton tipe W-400 A 1000 dengan kedalaman $10 \mathrm{~m}$ ditambah dengan pengakuan angkur pada kedalaman $1 \mathrm{~m}$ dari permukaan tanah yang dikaitkan oleh tie rod baja $\varnothing 7 \mathrm{~cm}$ sepanjang $14 \mathrm{~m}$ kepada blok angkur beton dengan tinggi blok angkur $1,5 \mathrm{~m}$ dan tebal $5 \mathrm{~cm}$ yang tertanam $0,5 \mathrm{~m}$ dari permukaan tanah, sehingga diperoleh nilai faktor keamanan yang dihitung dengan menggunakan program bantu Plaxis 2D V.8.2 sebesar 3,5814.
\end{abstract}

Kata kunci: longsor, program Plaxis, sheet pile, stabilitas lereng, sungai Lungun.

Diterima Redaksi : 14-08-2021 | Selesai Revisi : 20-09-2021 | Diterbitkan Online : 01-12-2021

\section{Pendahuluan}

\subsection{Latar belakang} merupakan salah satu kejadian yang paling sering terjadi di bidang geoteknik karena adanya peningkatan tegangan geser massa tanah atau penurunan kuat geser massa tanah, dengan kata lain kuat geser massa tanah tidak dapat menahan pembebanan yang bekerja.
Salah satu program bantu dibidang geoteknik yang berfungsi untuk membantu mempercepat analisis perhitungan dan meminimalisir kekeliruan pada saat perhitungan kestabilan lereng dengan perkuatan sheet pile yaitu dengan menggunakan program bantu Plaxis. Identifikasi serta penentuan faktor-faktor yang menjadi penyebab terjadinya longsor perlu dilakukan untuk mencari sumber permasalahan, lalu menemukan solusi yang tepat terhadap terjadinya longsor di lereng Sungai 
Lungun, Sabanar Baru, Kab. Bulungan, Kalimantan Utara.

Berdasarkan kejadian longsor yang terjadi di Sungai Lungun, maka ditentukan untuk penanggulangan longsor tersebut menggunakan alternatif sheet pile atau turap.

Salah satu program bantu dibidang geoteknik yang berfungsi untuk membantu mempercepat analisis perhitungan dan meminimalisir kekeliruan pada saat perhitungan kestabilan lereng dengan perkuatan sheet pile yaitu dengan menggunakan program bantu Plaxis. Berdasarkan pemaparan uraian latar belakang yang ada, maka penulis menentukan perumusan masalah yang terjadi, diantaranya :

a. Berapa nilai faktor aman (safety factor) pada lereng Sungai Lungun, Sabanar Baru, Kab. Bulungan, Kalimantan Utara?

b. Berapa ukuran dimensi sheet pile dan stabilitas yang di peroleh untuk solusi penanggulangan longsor pada lereng sungai yang di perkuat oleh sheet pile yang terjadi di Sungai Lungun, Sabanar Baru, Kab. Bulungan, Kalimantan Utara?

\section{Metode Penelitian}

2.1 Analisis Stabilitas Lereng Eksisting Menggunakan Metode Fellinus

Fellinus (1927) memperkenalkan metode Fellinus (Ordinary Method od Slice) yang didasarkan pada gaya yang memiliki sudut kemiringan sejajar dengan irisan , menghitung faktor keamanan dilakukan dengan terbentuk di antara garis vertikal dan jari-jari lingkaran menggunakan prinsip keseimbangan momen. Fellinus longsor.

mengemukakan asumsinya bahwa keruntuhan terjadi melalui perputaran sebidang tanah pada permukaan tanah longsor membentuk lingkaran dimana titik.

Fellenius mengemukakan asumsinya yaitu bahwa keruntuhan terjadi melalui perputaran sebidang tanah pada permukaan tanah longsor membentuk lingkaran dimana titik $\mathrm{O}$ menjadi pusat rotasi. Gaya normal $\mathrm{P}$ dianggap bekerja pada tengah-tengah slice/potongan pada metode ini. Resultan dari gaya-gaya yang terjadi antar irisan pada setiap irisan di asumsikan memiliki nilai sama dengan nol yaitu berarti resultan gaya-gaya yang terjadi antar irisan di abaikan. Jadi metode ini mengasumsikan dengan jumlah :

a. Posisi gaya normal $\mathrm{P}$ terletak di tengah pada tiap 1 irisan : $\mathrm{n}$

b. Resultan gaya antar irisan memiliki nilai nol : n-1

c. Total : 2 n-1

Berdasarkan asumsi diatas, maka dapat diperoleh nilai faktor keamanan dengan pengujian persamaan keseimbangan momen pada setiap irisan terhadap titik pusat rotasi.

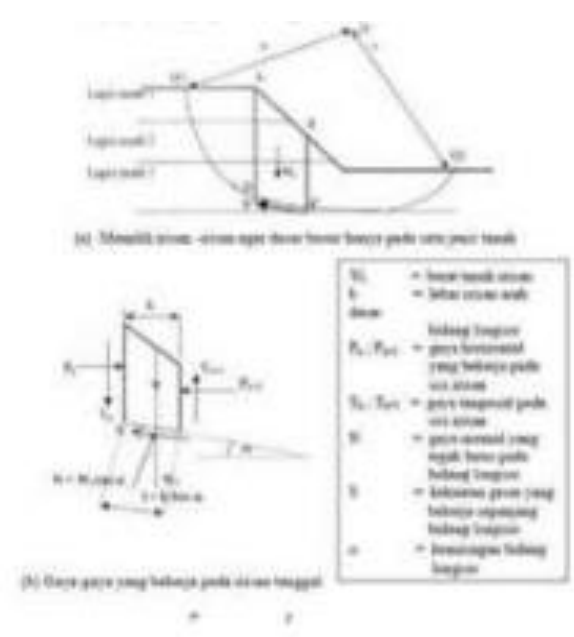

Gambar 1 Sistem gaya pada metode Fellinus

Gambar 1. diatas memperlihatkan suatu lereng dengan menggunakan sistem irisan untuk massa tanah itu sendiri (W) dan analisa komponen semua gaya yang terjadi dari massa tanah tersebut, yang tersusun oleh gaya-gaya antar potongan yang bekerja pada samping kanan potongan.

Pada dasar irisan, gaya berat (W) diturunkan menjadi gaya reaksi normal $\mathrm{Pw}$ yang bertindak tegak lurus terhadap alas irisan dan gaya tangensial Tw yang bekerja searah dengan irisan. Nilai dari lengan gaya (W) yaitu $\mathrm{X}$ $=\mathrm{R} \sin \alpha$, dimana $\mathrm{R}$ merupakan jari-jari lingkaran ongsor dan sudut $\alpha$ merupakan sudut pada titik $\mathrm{O}$ yang

Tekanan air pori akan bekerja di bagian bawah elemen yang berada di bawah air jika lereng terendam air atau permukaan air tanah yang berada di atas kaki lereng. Pada kondisi ini harus di hitung tahanan geser efektif, sedangkan gaya yang menjadi penyebab tetap di hitung secara total, sehingga formulasinya menjadi :

$F K=\frac{\sum[c \cdot l+(W \cdot \cos \alpha-u \cdot l) \cdot \tan \varphi]}{\sum(W \cdot \sin \alpha)}$ dimana :

$$
\begin{array}{ll}
\mathrm{c} & =\text { kohesi tanah pada bidang gelincir } \\
\phi & =\text { sudut geser dalam } \\
\mathrm{F} & =\mathrm{FK} \\
\mathrm{W} & =\text { berat irisan } \\
\mathrm{l} & =\text { panjang busur pada bidang gelincir } \\
\mathrm{u} & =\text { tinggi bidang gelincir }
\end{array}
$$

\subsection{Perencanaan Konstruksi Sheet Pile}

Adapun untuk menghitung perencanaan konstruksi sheet pile yang digunakan yaitu berpedoman kepada prinsip perancangan turap di angker yang terletak pada tanah kohesif dengan metode ujung bebas, yaitu sebagai berikut:

1. Analisa Gaya yang Bekerja pada Sheet Pile

a. Perhitungan koefisien tekanan tanah Tekanan tanah aktif

Journal of Applied Civil Engineering and Infrastructure (JACEIT) 


$$
K_{a}=\tan ^{2}\left(45-\frac{\Phi}{2}\right)
$$

Tekanan tanah pasif

$K_{p}=\tan ^{2}\left(45+\frac{\Phi}{2}\right)$

dimana :

$\phi=$ sudut geser dalam

b. Perhitungan tekanan tanah aktif

- Tekanan tanah aktif

- Tekanan tanah pada dasar galian $q^{\prime}=q+\sum \mathrm{y} \cdot H-2 . c$

dimana :

$\mathrm{q}=$ beban merata di belakang turap

$\mathrm{y}=$ berat jenis tanah

$\mathrm{c}=$ kohesi tanah

q' = Tekanan tanah aktif total

$\mathrm{H}=$ Jarak tekanan tanah aktif tehadap titik A

2. Perhitungan Kedalaman Sheet Pile

a. Perhitungan kedalaman penetrasi Sheet Pile (D)

b. Momen maksimum

c. Penentuan profil Sheet Pile

3. Perhitungan Angkur

a. Gaya pada angkur

b. Tahanan izin tie rod

c. Jarak blok angkur dari pusat ke pusat

d. Perencanaan diameter tie rod

e. Perhitungan tekanan tanah pada blok angkur

f. Perencanaan blok angkur

g. Tinggi blok angkur

h. Momen pada tie rod (jepit-jepit)

i. Tebal blok angkur

2.3 Analisis Stabilitas Lereng Menggunakan Program Plaxis.

Uraian berikut merupakan penjelasan secara rinci mengenai teknik analisis data dengan menggunakan program aplikasi Plaxis :

1. Plaxis Input

Permodelan untuk analisis pada Program Plaxis harus sesuai dengan kondisi lapangan yang akan dianalisis, tahapan permodelan lereng menggunakan program Plaxis yaitu :

a. Melakukan input data pada kotak dialog general settings. Tampilan general settings tersusun atas dua tab, yaitu project dan dimensions yang terlihat pada Gambar 2 dan Gambar 3, lalu pada tab project box di isi dengan nama lembar kerja baru diisi pada kotak title dan ukuran geometri diisi pada dimensions box.

b. Menggambar geometri kondisi lapangan secara Untuk mengetahui nilai faktor keamanan pada lereng dua dimensi penampang lereng yang akan yang akan dianalisis yaitu dilakukan input terhadap dianalisis.

c. Memilih kondisi batas (Standard fixities).

d. Melakukan input spesifikasi material pada menu material sets.

e. Menganalisis susunan 16arring elemen (Generated mesh).

f. Menentukan initial condition dan initial pore pressures untuk menentukan kondisi muka air tanah (MAT) dan $\mathrm{K}_{\mathrm{O}}$ Procedure. g. Melakukan generate water pressure kondisi phreatic level.

h. Menentukan closed consolidation boundary

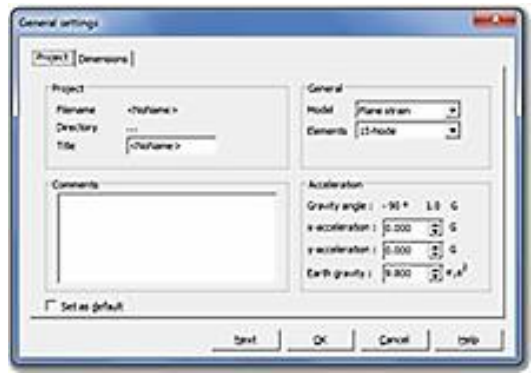

Gambar 2. Tampilan General Settings Project

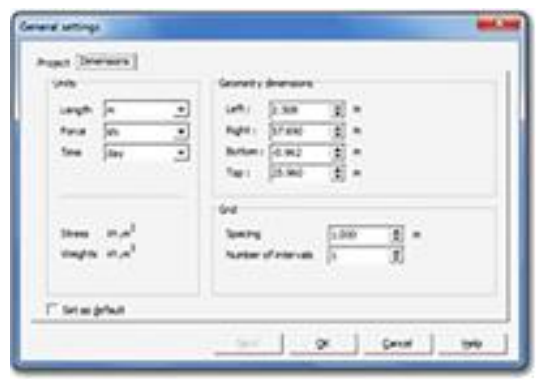

Gambar 3. Tampilan General Settings Dimensions

\section{Plaxis Calculations}

Plaxis calculations digunakan setelah menyelesaikan proses input pada kondisi lereng yang akan di analisis dan bisa otomatis terbuka setelah memilih toolbar calculate pada terakhir input. Setelah memilih toolbar calculate tersebut maka akan muncul tampilan seperti pada Gambar 4 untuk memasukan tahapan pekerjaan di lapangan sebagai berikut :

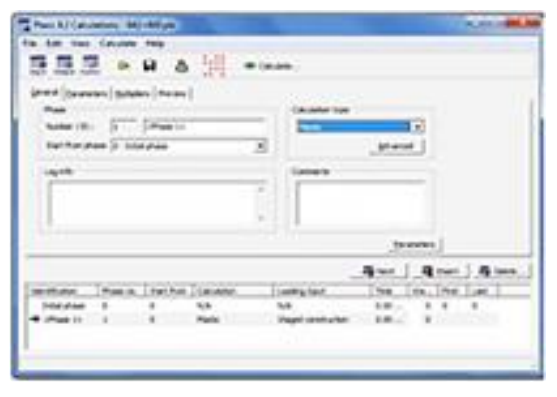

Gambar 4. Tampilan Plaxis Calculations tahap calculations sebagai berikut :

a. Pilih Phi/c Reduction pada calculation type. Lalu pilih incremental multipliers pada loading input, terakhir klik calculate.

b. Pilih titik nodal untuk penggambaran kurva perpindahan beban serta penggambaran garis tegangan.

Journal of Applied Civil Engineering and Infrastructure (JACEIT) 


\section{Plaxis Output}

Plaxis output dapat di buka lagi dengan memilih toolbar Plaxis output, atau dari start menu. Toolbar calculation pada calculation program juga dapat digunakan untuk memasukkan ke output program ketika telah selesai melakukan input dan telah selesai memilih titik yang akan ditinjau. Hasil analisis yang di peroleh dapat di tampilkan sebagai berikut :

a. Pilih menu peningkatan total dari menu deformasi. Tampilan akan menampilkan kenaikan dari semua titik nodal

b. Pilih tegangan efektif pada menu tegangan. Tampilan akan menampilkan besarnya dan arah tegangan utama efektif.

\section{Hasil dan Pembahasan}

\subsection{Data Hasil}

Data hasil yang diperoleh yaitu dengan mengajukan permohonan data kepada pihak-pihak terkait yang digunakan untuk dasar perhitungan perencanaan sheet pile yang merupakan data tanah kondisi eksisting Sungai Lungun dan data mengenai spesifikasi sheet pile yang akan digunakan sebagai material perencanaan ini.

Data yang digunakan yaitu data tanah, data cross section, dan data lainnya yang diperlukan di area muara atau hilir Sungai Lungun menuju ke Sungai Kayan di karenakan kondisi yang paling penting untuk di tangani pada area muara atau hilir sungai tersebut dengan lebar sungai kurang lebih sekitar $12 \mathrm{~m}$ dari tepi sungai ke tepi sungai.

\section{- Data Tanah}

Data tanah yang diperoleh merupakan data hasil pengujian lapangan berupa hasil data sondir dan hand boring. Adapun data hasil pengujian tanah yang di peroleh pada pengujian sondir dengan hasil nilai qc maksimalnya pada Tabel 1 berikut ini :

Tabel 1. Hasil uji sondir.

\begin{tabular}{ccccc}
\hline Titil- & $\begin{array}{c}\text { Kedalaman } \\
(\mathbf{m})\end{array}$ & $\begin{array}{c}\mathbf{Q c} \\
\left(\mathbf{k g} / \mathrm{cm}^{2}\right)\end{array}$ & $\begin{array}{c}\text { JHP } \\
(\mathbf{k g} / \mathrm{cm})\end{array}$ & $\begin{array}{c}\text { Fr } \\
(\%)\end{array}$ \\
\hline S-1 & 11.40 & 120.00 & 794.74 & 0.84 \\
S-2 & 11.00 & 130.00 & 83096 & 0.39
\end{tabular}

Uji tanah berikutnya yaitu pengujian handbor dengan hasil kedalaman maksimal berada pada tanah lempung abu-abu yang berarti merupakan tanah kohesif yang memiliki kedalaman dari $1.00 \mathrm{~m}$ sampai dengan $2.00 \mathrm{~m}$, yaitu HB-03 dengan hasil dapat dilihat pada Tabel 2 dan Tabel 3 berikut ini :
Tabel 2. Tebal lapisan tanah hasil uji Handbor.

\begin{tabular}{|c|c|c|c|}
\hline Lap. & $\begin{array}{l}\text { Kedalaman } \\
\text { (m) }\end{array}$ & $\begin{array}{l}\text { TebalLap } \\
\text { (m) }\end{array}$ & Jenis Tanah \\
\hline 1 & $0.00-1.40$ & 1.40 & $\begin{array}{c}\text { Lempung Abu } 2 \\
\text { kecoklatan }\end{array}$ \\
\hline 2 & $1.40-2.00$ & 0.60 & Lempung Abu2 \\
\hline 3 & $2.00-11.00$ & 9.00 & Lempung Abu2 \\
\hline
\end{tabular}

Sum ber: Data diolah oleh Penulis, (2021)

Tabel 3. Parameter tanah hasil Handbor.

\begin{tabular}{|c|c|c|}
\hline Pengujian Lab. & Hasil & Satuan \\
\hline Kader air (৫) & 56.483 & $\%$ \\
\hline Berat Jeris (Gs) & 2.590 & $\mathrm{gr} / \mathrm{cm}^{3}$ \\
\hline Berat Isi $(\mathrm{Y})$ & 1.703 & $\mathrm{gr} / \mathrm{cm}^{3}$ \\
\hline Kohesi (c) & 0.026 & $\mathrm{~kg} / \mathrm{cm}^{2}$ \\
\hline Sudut Geeer (Ø) & 24.823 & $=$ \\
\hline Batas Cair (LL) & 39.993 & $\%$ \\
\hline Batas Plastis (PL) & 27.298 & $\%$ \\
\hline Indeks Plastisitas (IP) & 12.695 & $\%$ \\
\hline Kuat Telan Bebas (qu) & 0.367 & $\mathrm{~kg} / \mathrm{cm}^{2}$ \\
\hline
\end{tabular}

- Data Sheet Pile

Data sheet pile diperoleh dari brosur PT. WIKA Beton yang merupakan anak perusahaan dari PT. Wijaya Karya (persero) Tbk dengan spesifikasi produk sheet pile tipe Corrugated Prestressed Concrete (CPC) yang di produksi untuk di jual pada proyek konstruksi terkait, adapun data sheet pile yang diperoleh dapat dilihat pada Gambar 5 berikut ini :

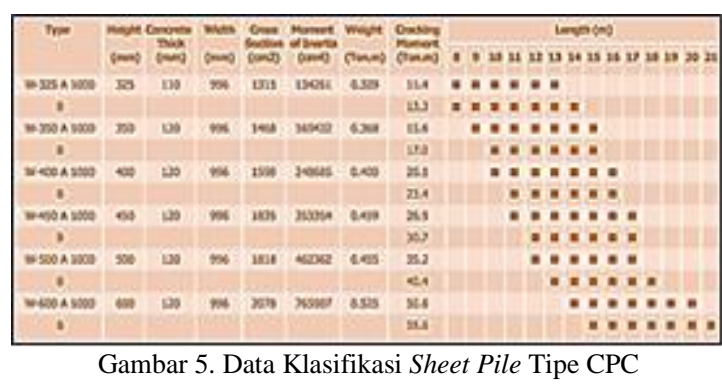

- Data Kondisi Eksisting Sungai

Kondisi eksisting muara atau hilir Sungai Lungun dari hasil pengukuran dan data DED yang di peroleh, serta hasil pengolahan data hidrologi pada area tersebut dengan nilai High Water Level $(\mathrm{HWL})+4,551 \mathrm{~m}$ dan nilai Low Water Level (LWL) +2,514 m telah dihasilkan gambar cross section untuk mewakili kondisi potongan melintang Sungai Lungun yang dapat dilihat pada Gambar 6 berikut ini : 


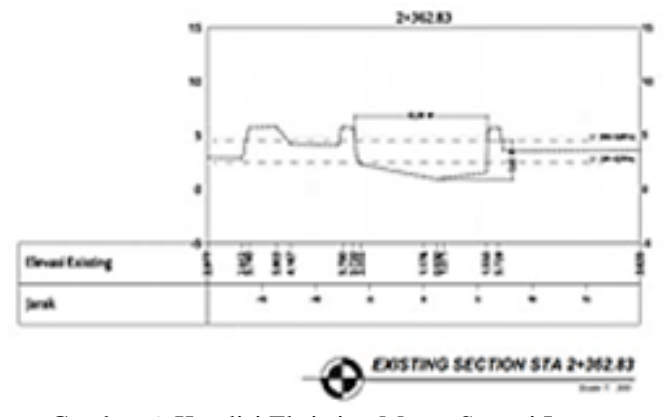

Gambar 6. Kondisi Eksisting Muara Sungai Lungun

3.2 Analisis Stabilitas Lereng Kondisi Eksisting Menggunakan Metode fellinus

Perhitungan analisis ketabilan lereng menggunakan Metode Fellinus diperlukan data penunjang yang telah diketahui terlebih dahulu yaitu data parameter tanah pada lereng tersebut ( $\left.\mathrm{c}, \varphi_{1} \gamma\right)$. Data lereng yang diperoleh dari hasil penelitian sebelumnya adalah sebagai berikut :

- Lapisan tanah 1 (lempung abu-abu)

$L_{l}=2 \mathrm{~m} ; \gamma_{l}=1,703 \mathrm{gr} / \mathrm{cm} 3=16,701 \mathrm{kN} / \mathrm{m}^{3}$

$c_{1}=0,026 \mathrm{~kg} / \mathrm{cm} 2=2,550 \mathrm{kN} / \mathrm{m}^{2}$

$\varphi_{1}=24,823^{\circ}$

- Lapisan tanah 2 (lempung abu-abu)

$L 2=9 \mathrm{~m} ; \quad \gamma_{2}=26,507 \mathrm{kN} / \mathrm{m}^{3}$

$c 2=1 / 2 \times$ qu $=1 / 2 \times 0,367 \mathrm{~kg} / \mathrm{cm}^{2}=17,995 \mathrm{kN} / \mathrm{m}^{2}$ $\varphi_{2}=4,823^{\circ}$

Dengan menggunakan data tanah diatas, setelah itu bidang longsor tersebut di gambarkan dengan program bantu Autocad seperti yang terlihat pada Gambar 7 dan Gambar 8 berikut ini :

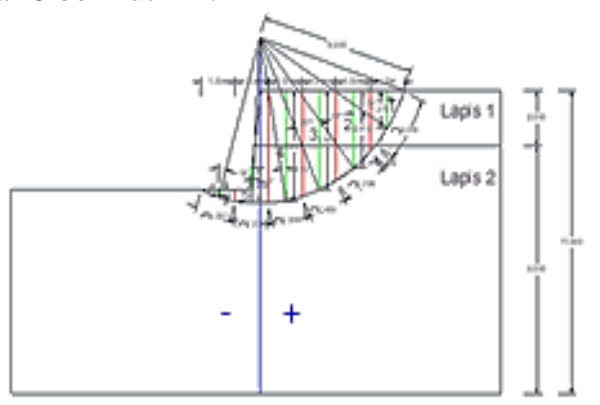

Gambar 7. Pembagian Bidang Longsor dlm Bentuk Irisan

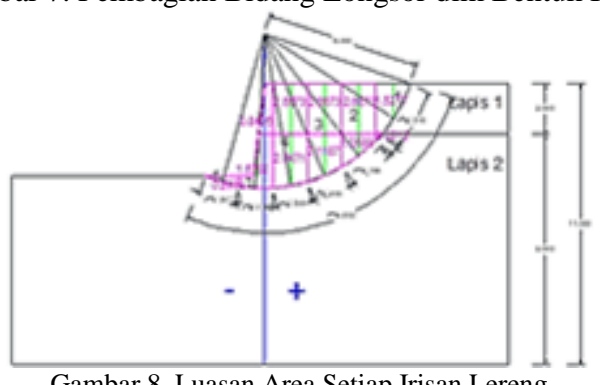

Gambar 8. Luasan Area Setiap Irisan Lereng
Tabel 4. Tabulasi perhitungan beban dengan Metode Fellenius.

\begin{tabular}{|c|c|c|c|c|c|c|}
\hline \multirow{2}{*}{ No } & \multirow{2}{*}{$\begin{array}{c}\mathrm{C} \\
(\mathrm{kPa})\end{array}$} & \multirow{2}{*}{$\begin{array}{c}\phi \\
(\circ)\end{array}$} & \multirow{2}{*}{$\begin{array}{c}1 \\
(\mathbf{m})\end{array}$} & \multicolumn{2}{|c|}{$A\left(m^{2}\right)$} & \multirow{2}{*}{$\underset{(\mathbf{k N})}{\mathbf{W}}$} \\
\hline & & & & 1 & 2 & \\
\hline 1 & 4,263 & 60,244 & 2,605 & 11,106 & 1,528 & 0,021 \\
\hline 2 & 17,995 & 24,823 & 1,706 & 30,700 & 2,667 & 0,990 \\
\hline 3 & 17,995 & 24,823 & 1,455 & 26,183 & 2,667 & 2,076 \\
\hline 4 & 17,995 & 24,823 & 1,356 & 24,401 & 2,667 & 2,613 \\
\hline 5 & 17,995 & 24,823 & 1,338 & 24,078 & 0,841 & 1,645 \\
\hline 6 & 17,995 & 24,823 & 1,391 & 25,031 & 0,000 & 0,256 \\
\hline$\Sigma$ & & & & 141,499 & & \\
\hline
\end{tabular}

Tabel 5. Tabulasi perhitungan faktor keamanan menggunakan Metode Fellenius.

\begin{tabular}{|c|c|c|c|c|c|c|c|c|c|c|}
\hline No & $\mathrm{Cl}(\mathbf{k N})$ & $\mathbf{W}(\mathbf{k N})$ & $\begin{array}{l}a \\
(0)\end{array}$ & $\begin{array}{c}\text { W.cos } u \\
(\mathbf{k N})\end{array}$ & $\begin{array}{c}\text { W.sin } \alpha \\
(\mathbf{k N})\end{array}$ & $\begin{array}{c}\text { u } \\
(\mathrm{m})\end{array}$ & ul (kN) & $\begin{array}{c}\text { Ceos } u \\
-\mathrm{ul} \\
(\mathrm{kN}) \\
\end{array}$ & $\begin{array}{c}\text { Weos } \alpha \\
- \\
\text { ul.tan } \phi \\
\end{array}$ & $\begin{array}{c}\mathrm{cl}+ \\
\mathrm{W} \cos \alpha- \\
\text { ul.tan } \phi\end{array}$ \\
\hline 1 & 11,106 & 26,065 & 57 & 14,196 & 21,860 & 1,372 & 35,050 & $-20,853$ & $-36,477$ & $-25,371$ \\
\hline 2 & 30,700 & 70,791 & 38 & 55,784 & 43,583 & 2,819 & 47,162 & 8,622 & 3,988 & 34,688 \\
\hline 3 & 26,183 & 99,575 & 23 & 91,659 & 38,907 & 3,597 & 51,324 & 40,335 & 18,657 & 44,840 \\
\hline 4 & 24,401 & 113,796 & 10 & 112,067 & 19,761 & 3,997 & 53,151 & 58,916 & 27,252 & 51,653 \\
\hline 5 & 24,078 & 57,643 & -3 & 57,564 & $-3,017$ & 1,292 & 16,953 & 40,611 & 18,785 & 42,863 \\
\hline 6 & 25,031 & 6,786 & -16 & 6,523 & $-1,870$ & 0,231 & 3,151 & 3,372 & 1,560 & 26,591 \\
\hline \multirow[t]{2}{*}{$\Sigma$} & 141,499 & & & & 119,22 & & & & & 175,26 \\
\hline & & & & & & & & & FK & 1,470 \\
\hline
\end{tabular}

\subsection{Perencanaan Konstruksi Sheet Pile}

Hasil perhitungan analisa stabilitas lereng eksisting diatas memiliki faktor keamanan 1,470 maka perlu meningkatkan nilai faktor keamanan, dengan menambah perkuatan dengan sheet pile pada lereng tersebut. Datadata Analisa dan pembahasan dalam perencanaan sheet pile Sungai Lungun STA 2+311,76 - STA 2+399,53 di Tanjung Selor Kebupaten Bulungan dapat dilihat pada Tabel 6 sebagai berikut:

Tabel 6. Data lapisan kedalaman tanah perencanaan sheet pile.

\begin{tabular}{|lc|}
\hline \multicolumn{1}{|c|}{ Keterangan } & Kedalaman \\
\hline Tinggi dinding sheet pile dari dasar galian ke perm ukaan tanah & $\mathrm{H}=4,50 \mathrm{~m}$ \\
Tinggi plat beton trotoar & $\mathrm{hl}=0,10 \mathrm{~m}$ \\
Jarak dari muka tanah ke tie rod & $\mathrm{h} 2=1,00 \mathrm{~m}$ \\
Jarak dari lapisan tanah pertama ke tie rod & $\mathrm{h}=1,00 \mathrm{~m}$ \\
Jarak dari lapisan tanah pertama ke dasar galian & $\mathrm{h} 4=2,50 \mathrm{~m}$ \\
Kedalaman blok angkur tertanam di dalam tanah & $\mathrm{Ha}=2,00 \mathrm{~m}$ \\
Tinggi aktual blok angkur & $\mathrm{ha}=0,50 \mathrm{~m}$ \\
Beban terbagi rata (plat trotoar $=2,4.0,1.9,807)$ & $\mathrm{q}=2,354 \mathrm{kN} / \mathrm{m}^{2}$ \\
Tebal lapisan tanah ke 1 & $\mathrm{HT} 1=2,00 \mathrm{~m}$ \\
Tebal lapisan tanah ke 2 & $\mathrm{HT} 2=9,00 \mathrm{~m}$ \\
Sum ber: Data diolah oleh Penulis, (2021) & \\
\hline
\end{tabular}

Dari data lapisan kedalaman tanah pada Tabel 6 diatas, penggambaran desain konstruksi sheet pile menggunakan program bantu Autocad yang dapat dilihat pada Gambar 9 berikut ini :

Dari data tanah dan penggambaran bidang longsor diatas, maka dilanjutkan dengan perhitungan stabilitas lereng dengan Metode Fellenius yang dapat dilihat pada Tabel 4 dan Tabel 5 berikut ini : 


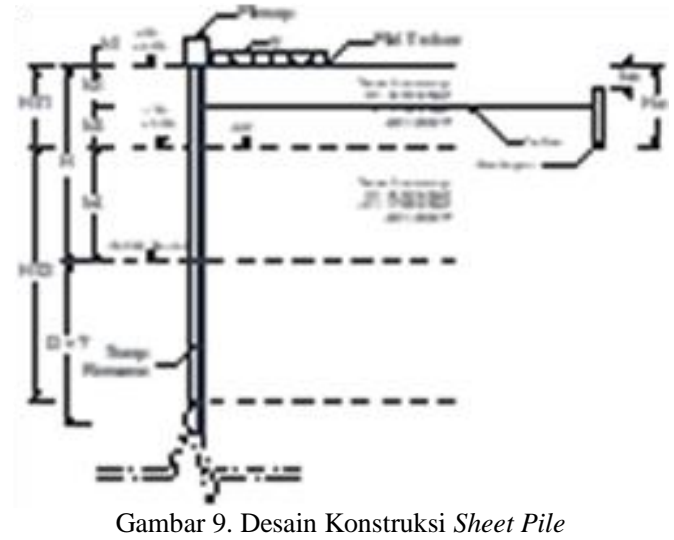

Gambar 9. Desain Konstruksi Sheet Pile

- Analisa Gaya yang Bekerja Pada Sheet Pile Perhitungan koefisien tekanan tanah

a. Koefisien tekanan tanah aktif

$K_{a}=\tan ^{2}\left(45-\frac{\Phi}{2}\right)=\tan ^{2}\left(45-\frac{24.823}{2}\right)=0,409$

b. Koefisien tekanan tanah pasif

$K_{p}=\tan ^{2}\left(45+\frac{\Phi}{2}\right)=\tan ^{2}\left(45+\frac{24.823}{2}\right)=2,447$

- Perhitungan tekanan tanah aktif

a. Tekanan tanah aktif

Perhitungan tekanan tanah aktif dapat dilihat pada Tabel 7 berikut ini :

Tabel 7. Tabulasi perhitungan tekanan tanah aktif

\begin{tabular}{|c|c|c|c|}
\hline No & Notasi & Urzinn & $\mathrm{Pa}\left(\mathrm{kN} / \mathrm{a}^{\lambda}\right)$ \\
\hline 1. & $\mathrm{~Pa}$ & q- $\mathrm{Ka}=2,354,0,409$ & 0,962 \\
\hline 2. & $\mathrm{Paz}$ & $(h y+h) \cdot x \cdot K a=(1+1) \cdot 16,701,0,409$ & 13.649 \\
\hline 3. & Pas & $(q+(b+h) \cdot, 71) \cdot K_{2}=(2,354+(1+1), 16,701), 0,409$ & 14,611 \\
\hline 4. & Pas & hy. $\left(\mathrm{y}-\mathrm{\gamma}_{\mathrm{w}}\right) \cdot \mathrm{Kn}=2,5,16,701,0,909$ & 17,061 \\
\hline 5. & Paw & h. $-\gamma^{w}=2,5,9,807$ & 24,517 \\
\hline 6. & $\mathrm{P}_{2 C_{1}}$ & $=2 \cdot 9 \cdot \sqrt{K a}=2 \cdot 2,550 \cdot \sqrt{0,409}$ & $-3,260$ \\
\hline 7 . & $\mathrm{P}_{2 \mathrm{C2}}$ & $-2, \mathrm{~g}, \sqrt{\mathrm{K}} \mathrm{a}=-2,17,995, \sqrt{0,409}$ & $-23,007$ \\
\hline
\end{tabular}

b. Tekanan tanah pada kedalaman dasar galian

$$
\begin{aligned}
\mathrm{q}^{\prime} & =\mathrm{q}+\sum \mathrm{\gamma} \cdot \mathrm{H}-2 \cdot \mathrm{c} \\
& =\mathrm{q}+\mathrm{\gamma}_{1} \cdot\left(\mathrm{h}_{2}+\mathrm{h}_{3}\right)+\mathrm{\gamma}_{2} \cdot \mathrm{h}_{4}-2 \cdot\left(\mathrm{c}_{1}+\mathrm{c}_{2}\right) \\
& =2,354+16,701 \cdot(1+1)+26,507 \cdot 2,5-2 \cdot(2,550+17,995) \\
& =60,933 \mathrm{kN} / \mathrm{m}^{2}
\end{aligned}
$$

\section{c. Tekanan tanah aktif total}

\begin{tabular}{|c|c|c|c|}
\hline No & Notasi & Uraian & $\mathrm{Ta}(\mathrm{kN})$ \\
\hline 1. & $\mathrm{Ta}_{1}$ & $\mathrm{~Pa}_{1 .}\left(\mathrm{h}_{2}+\mathrm{h}_{3}\right)=0,962 .(1+1)$ & 1,924 \\
\hline 2. & $\mathrm{Ta}_{2}$ & $\mathrm{~Pa}_{2} \cdot\left(\mathrm{h}_{2}+\mathrm{h}_{3}\right) \cdot 1 / 2=13,649 \cdot(1+1) \cdot 1 / 2$ & 13,649 \\
\hline 3. & Taz & $\mathrm{Pa}_{3} \cdot \mathrm{h}_{4}=14,611.2,5$ & 36,527 \\
\hline 4. & $\mathrm{Ta}_{4}$ & $\mathrm{~Pa}_{4} \cdot \mathrm{h} 4 \cdot 1 / 2=17,061 \cdot 2,5 \cdot 1 / 2$ & 21,326 \\
\hline 5. & Taw & Paw $\cdot h_{4} \cdot 1 / 2=24,517 \cdot 2,5,1 / 2$ & 30,646 \\
\hline 6. & Tacl & Pacl $.\left(h_{2}+h_{3}\right)=-3,260 .(1+1)$ & $-6,520$ \\
\hline \multirow[t]{2}{*}{7.} & $\mathrm{Tac}_{2}$ & $\mathrm{Pac}_{2} \cdot \mathrm{h}_{4}=-23,007 \cdot 2,5$ & $-57,517$ \\
\hline & & & 40,035 \\
\hline
\end{tabular}

Perhitungan tekanan tanah aktif total dapat dilihat pada Tabel 8 berikut ini :

Tabel 8. Tabulasi perhitungan tekanan tanah aktif

d. Jarak tekanan tanah aktif tehadap tie rod (titik A)

Perhitungan jarak tekanan tanah aktif terhadap titik A

\begin{tabular}{|c|c|c|c|}
\hline No & Notasi & U raian & $\mathrm{Ta}(\mathrm{kN})$ \\
\hline 1. & Lal & $1 / 2 \cdot\left(h_{2}+h_{3}\right)-h_{2}=1 / 2 \cdot(1+1)-1$ & 0,00 \\
\hline 2. & $\mathrm{~L}_{a_{2}}$ & $2 / 3 \cdot\left(h_{2}+h_{3}\right)-h_{2}=1 / 3 \cdot(1+1)-1$ & 0,33 \\
\hline 3. & Las & $1 / 2 \cdot h_{4}+h_{3}=1 / 2 \cdot 2,5+1$ & 2,25 \\
\hline 4. & $\mathrm{La}_{4}$ & $2 / 3 . h_{4}+h_{3}=2 / 3 \cdot 2,5+1$ & 2,67 \\
\hline 5. & Law & $1 / 3 . h_{4}+h_{3}=2 / 3.2,5+1$ & 2,67 \\
\hline 6. & Lacl & $1 / 2 \cdot\left(h_{2}+h_{3}\right)-h_{2}=1 / 2 \cdot(1+1)-1$ & 0,00 \\
\hline \multirow[t]{2}{*}{7.} & $\mathrm{Lac}_{2}$ & $1 / 2 \cdot\left(h_{4}+h_{3}\right)=1 / 2 \cdot(2,5+1)$ & 1,75 \\
\hline & & & 40,035 \\
\hline
\end{tabular}
atau titik tie rod dapat dilihat pada Tabel 9 berikut ini :
Tabel 9. Tabulasi perhitungan jarak tekanan tanah aktif terhadap titik A

Sumber : Data diolah oleh Penulis, (2021)

e. Momen tekanan tanah aktif terhadap tie rod (titik A)

Momen tekanan tanah aktif adalah titik pusat tekanan

\begin{tabular}{|c|c|c|c|}
\hline No & Notasi & Uraian & Ta $(\mathrm{kN})$ \\
\hline 1. & $\mathrm{MPa} 1$ & $\mathrm{Ta} 1 . \mathrm{La} 1=1,924.0$ & 0,000 \\
\hline 2. & $\mathrm{MPa} 2$ & $\mathrm{Ta} 2 . \mathrm{La} 2=13,649.0,33$ & 4,550 \\
\hline 3. & $\mathrm{MPa} 3$ & $\mathrm{Ta} 3 . \mathrm{La} 3=36,527.2,25$ & 82,185 \\
\hline 4. & MPa4 & Ta4 . La4 $=17,326.2,67$ & 56,870 \\
\hline 5. & MPaw & Taw1 . Law1 $=30,646.2,67$ & 81,722 \\
\hline 6. & MPac1 & Tac1. Lac1 $=-6,520.0$ & 0,000 \\
\hline 7. & $\mathrm{MPac} 2$ & Tac2 $. \mathrm{Lac} 2=-57,517.1,75$ & $-100,654$ \\
\hline
\end{tabular}
tanah aktif yang ditinjau terhadap titik A yaitu tie rod yang dapat dilihat pada Tabel 10 berikut ini :

Tabel 10. Tabulasi perhitungan momen tekanan tanah

umber : Data diolah oleh Penulis, (2021)

f. Jarak titik tangkap tekanan tanah aktif terhadap titik A

Perhitungan jarak dari titik tangkap tekanan tanah aktif terhadap tie rod (titik A) :y $=\frac{\sum M P a}{\sum P a}=\frac{124,673}{40,035}=3,11 \mathrm{~m}$ g. Diagram tekanan tanah aktif

Penggambaran diagram tekanan tanah aktif menggunakan program bantu Autocad dapat dilihat pada Gambar 10 berikut ini :

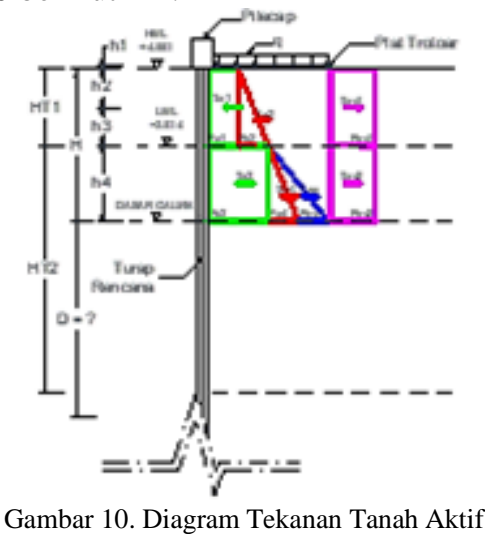

- Perhitungan Kedalaman Sheet Pile.

a. Perhitungan kedalaman penetrasi sheet pile (D) $\sum M A=0$

$\sum M P a-D \cdot\left(4 c-q^{\prime}\right) \cdot\left(h_{3}+h_{4}+1 / 2 \cdot D\right)=0$

$124,673-D \cdot(4 \cdot 17,995-60,933) \cdot(1+2,5$

$$
+1 / 2 \cdot D)=0
$$

$$
-5,524 D^{2}-38,666 D+124,673=0
$$

Journal of Applied Civil Engineering and Infrastructure (JACEIT) 
Untuk mencari nilai D, maka digunakan rumus abc c. Jarak blok angkur dari pusat ke pusat

sebagai berikut :

$X_{1,2}=\frac{-b \pm \sqrt{b^{2}-4 a c}}{2 a}$
$=\frac{-(-38,666) \pm \sqrt{(-38,666)^{2}-4 \cdot(-5,524) \cdot 124,673}}{2 \cdot(-5,524)}$

Maka nilai untuk $X_{1}$ dan $X_{2}$, yaitu $X_{1}=-9,40$ dan $X_{2}$ $=2,40$

Dari rumus abc yang telah dihitung diatas, maka di peroleh nilai $\mathrm{D}=\mathrm{X}_{2}=2,40 \mathrm{~m}$

Kedalaman penetrasi sheet pile : D' $=1,4$. D = 1,4 . 2,40 $=3,36 \mathrm{~m}$

Panjang sheet pile total yang di perlukan $: P=H+D^{\prime}=T^{\prime}$ $4,5+3,36=7,86 \mathrm{~m} \approx 8,00 \mathrm{~m}$

b. Momen maksimum

$$
\begin{aligned}
& M \max =\sum P a\left[\left(\frac{\sum P a}{4 c-q^{\prime}}+y\right)-\left(\frac{1}{2} \cdot \frac{\sum P a}{4 c-q^{\prime}}\right)\right] \\
& M \max =40,035\left[\left(\frac{40,035}{4 \cdot 17,995-60,933}+3,11\right)-\right. \\
& \left.\left(\frac{1}{2} \cdot \frac{40,035}{4.17,995-60,933}\right)\right] \\
& =40,035 \cdot(6,738-1,812) \\
& =197,215 \mathrm{kN} \cdot \mathrm{m} \\
& =21 \text { Ton.m }
\end{aligned}
$$

c. Penentuan profil sheet pile.

Dari hasil perhitungan kedalaman sheet pile diatas, maka diambil panjang sheet pile yang diperlukan yaitu $8 \mathrm{~m}$, sedangkan dari perhitungan momen maksimal dan dilihat dari

tabel pada Gambar 5 mengenai klasifikasi sheet pile dari

PT. WIKA Beton, maka digunakan sheet pile dengan tipe W-400 A 1000 dengan panjang sheet pile $10 \mathrm{~m}$ dan nilai cracking moment $=21,1$ Ton.m yang dapat dilihat pada Gambar 11 berikut ini :

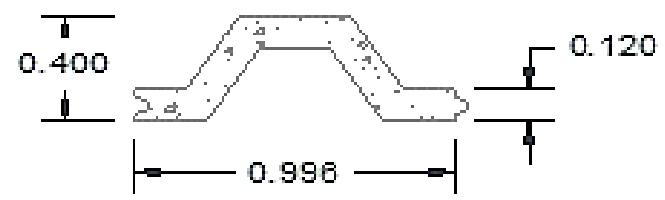

Gambar 11. Dimensi Profil Sheet Pile Tipe W-400 A 1000

Melihat hasil perhitungan momen maksimal, maka sheet pile yang di tentukan memenuhi syarat cracking moment yaitu :

Mmax < Cracking moment

$21<21,1 \ldots$. OK !!!

- Perhitungan Angkur

a. Gaya pada angkur

$\mathrm{T}=\sum \mathrm{Pa}-\left(4 \mathrm{c}-\mathrm{q}^{\prime}\right)$.D

$=40,035-(4$. 17,995-60,933) . 2,40

$=13,511 \mathrm{kN} / \mathrm{m}$

b. Tahanan izin tie rod

$$
\begin{aligned}
& \text { Pall }=\frac{\sum M P a}{S F} \\
& \text { Pall }=\frac{124,673}{2}=62,336 \mathrm{kN} . \mathrm{m}
\end{aligned}
$$

Jarak blok angkur dari pusat ke pusat sama dengan jarak tie rod dari pusat ke pusat

$S=\frac{P a l l}{\sum P a}$

$\begin{aligned} S & =\frac{62,336}{40,035} \\ & =1,56 \mathrm{~m}\end{aligned}$

Maka digunakan jarak blok angkur dari pusat ke pusat $\mathrm{S}$

$=1 \mathrm{~m}$ sesuai dengan jarak lebar as ke as sheet pile yang kurang dari jarak blok angkur dari pusat ke pusat pada perhitungan diatas.

d. Perencanaan diameter tie rod

$\mathrm{T}^{\prime}=\mathrm{T} \times \mathrm{S}$

$=13,511.1$

$$
=13,511 \mathrm{kN} / \mathrm{m}
$$

$\sigma_{\text {angkur baja }}=3900 \mathrm{~kg} / \mathrm{cm}^{2}$

$\sigma_{\text {angkur baja }}=\frac{T \prime}{A}$

$\sigma_{\text {angkur baja }}=\frac{T^{\prime} \cdot 1000}{\frac{1}{4} \cdot \pi \cdot \emptyset^{2}}$

$\varnothing=\sqrt{\frac{13,511 \cdot 10000}{\frac{1}{4} \cdot \frac{22}{7} \cdot 3900}}=6,64 \mathrm{~cm}$

Maka digunakan diameter tie $\operatorname{rod} \varnothing=7 \mathrm{~cm}$

e. Perhitungan tekanan tanah pada blok angkur

Di asumsikan : ha $\quad=0,5 \mathrm{~m}$

$\mathrm{Ha}=2 \mathrm{~m}$

$\mathrm{f}^{\prime} \mathrm{c} \quad=30 \mathrm{Mpa}$

Apabila $\mathrm{h} \leq \mathrm{H} / 3$, maka dianggap tinggi papan angkur $=$ $\mathrm{H}$, dan termasuk jenis blok angkur memanjang dekat permukaan tanah.

$\mathrm{h} \leq \mathrm{H} / 3$

$0,5 \leq 2 / 3$

$0,5 \leq 0,667 \ldots$ OK !!!

Tekanan tanah aktif pada blok angkur

$\mathrm{Pa}=1 / 2 \times \gamma_{1} \times \mathrm{Ka} \times \mathrm{H}^{2}=1 / 2 \times 16,701 \times 0,409 \times 2^{2}=$ $13,649 \mathrm{kNm}$

Tekanan tanah pasif pada blok angkur

$\mathrm{Pp}=1 / 2 \times \gamma_{1} \times \mathrm{Kp} \times \mathrm{H}^{2}=1 / 2 \times 16,701 \times 2,447 \times 2^{2}=$ $81,739 \mathrm{kNm}$

f. Perencanaan blok angkur

Panjang tie rod direncanakan sepanjang $\mathrm{X}=14 \mathrm{~m}$. Penentuan panjang tie rod yaitu dengan penggambaran grafis menggunakan program bantu Autocad yang dapat dilihat pada Gambar 12 berikut ini : 


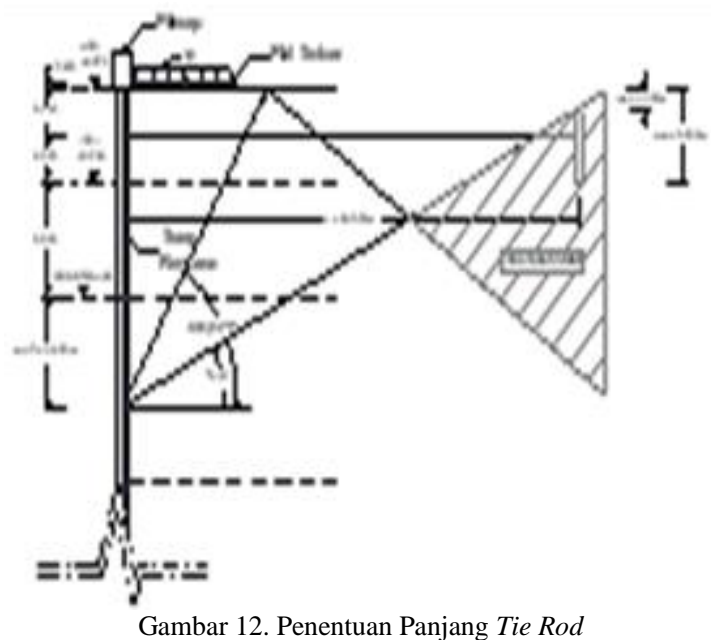

g. Tinggi blok angkur

$\mathrm{L} \quad=\mathrm{Ha}-\mathrm{ha}=2-0,5=1,5 \mathrm{~m}$

Angkur pada tanah kohesif

$\mathrm{T} \leq \mathrm{L}(\mathrm{Pp}-\mathrm{Pa})+2 \mathrm{cH}^{2}$

$13,511 \leq \mathrm{L} .68,091+20,398$

$\mathrm{L} \geq-0,101$

$1,5 \geq-0,101$

Maka digunakan tinggi blok angkur

$\mathrm{L}=1,5 \mathrm{~m} \ldots \mathrm{Ok}$ !!!

h. Momen pada tie rod (jepit-jepit)

$\mathrm{q}=\mathrm{T}=13,511 \mathrm{kN} / \mathrm{m}$

$M=1 / 12$. q. $S^{2}$

$=1 / 12 \cdot 13,511 \cdot 1^{2}$

$=1,117 \mathrm{kNm}$

i. Tebal blok angkur

$b=\sqrt{\frac{6 \cdot M}{f^{\prime} c \cdot L}}=\sqrt{\frac{6 \cdot 1,117}{30 \cdot 1000 \cdot 1,5}}=0,012 \mathrm{~m}$

$=1,22 \mathrm{~cm}$

Maka digunakan tebal blok angkur $b=5 \mathrm{~cm}$

j. Desain blok angkur

Dari hasil perhitungan blok angkur diatas, maka dapat dilihat dimensional hasil penggambaran dengan program bantu Autocad pada Gambar 13 berikut ini :

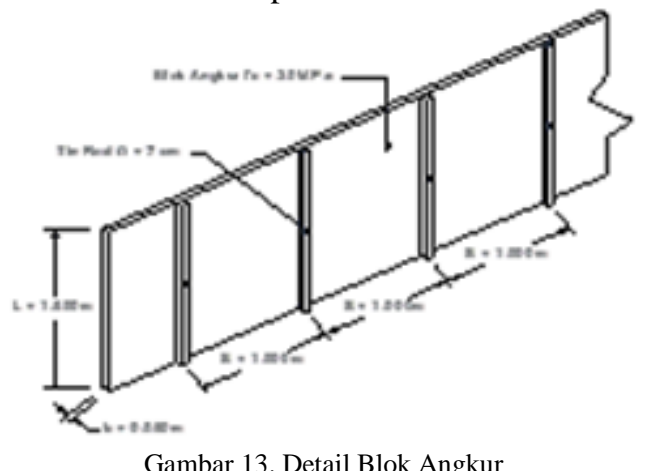

3.4 Analisis Stabilitas Lereng Menggunakan Program Plaxis

- Kondisi Lereng Eksisting

Pada simulasi analisis kelongsoran menggunakan program Plaxis V.8.2 di input data penampang cross section yang telah diperoleh serta dengan data komponen lapisan tanah dari hasil pengujian laboratorium yang dilengkapi dengan parameter tanah dari setiap lapisan tanah. Analisis ini menggunakan model Mohr-Coulomb yang dengan melakukan input beberapa parameter tanah. Proses perhitungan dengan Plaxis pada kondisi awal memiliki 2 fase, yaitu fase perhitungan kondisi awal lereng dan perhitungan angka keamanan (safety factor). Hasil running program Plaxis 2D tersebut dapat dilihat dari Gambar 14 dan setelah di kalkulasikan, maka angka keamanan (safety factor) diperoleh seperti pada Gambar 15 berikut :

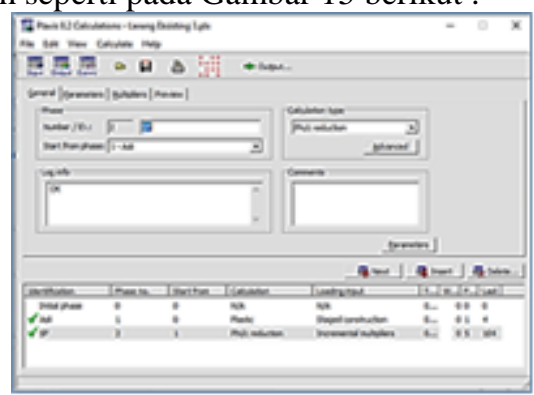

Gambar 14. Tahapan Perhitungan Lereng Eksisting Menggunakan

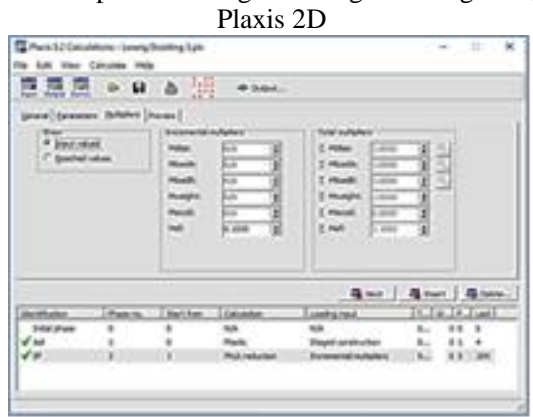

Gambar 15. Hasil Perhitungan Safety Factor Lereng Eksisting Menggunakan Plaxis 2D

Dari hasil analisis menggunakan program Plaxis 2D tersebut, nilai faktor keamanan lereng yang diperoleh yaitu 1,1092 .

- Kondisi Lereng di Tambah Perkuatan Sheet Pile dengan Angkur

Pada analisis ini menggunakan data parameter tanah yang sama dengan kondisi eksisting dengan tambahan data parameter sheet pile dan angkur yang di input pada program Plaxis 2D pada perencanaan ini menggunakan sheet pile beton tipe W-400 A 1000 dengan pemasangan kedalaman rencana $10 \mathrm{~m}$ dengan angkur sepanang $14 \mathrm{~m}$. 


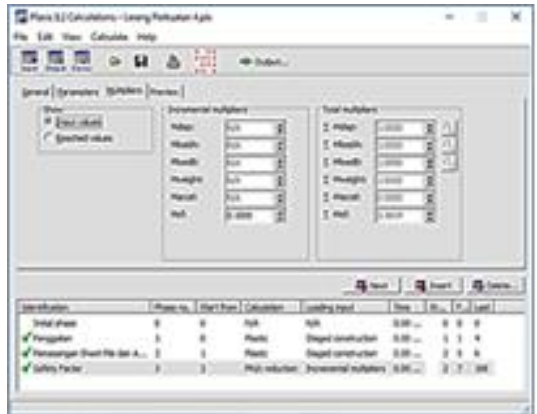

Gambar 16. Hasil Perhitungan Safety Factor Lereng Memakai Perkuatan Sheet Pile dengan Angkur Menggunakan Plaxis 2D

Setelah dilakukan proses perhitungan menggunakan progam bantu Plaxis 2D V.8.2, maka diperoleh nilai faktor keamanan lereng yaitu sebesar 3,5814. Dari hasil analisis faktor keamanan lereng dengan nilai lebih dari 1,5 tersebut, maka lereng telah dapat dikatakan stabil.

\section{Kesimpulan}

Dari hasil analisis dan perhitungan pada bab sebelumnya, dapat ditarik kesimpulan yaitu:

1. Nilai faktor keamanan (FS) pada lereng Sungai Lungun, Sabanar Baru, Kab. Bulungan, Kalimantan Utara dengan menggunakan perhitungan manual Metode Fellenius diperoleh nilai sebesar 1,470 dan perhitungan dengan menggunakan program bantu Plaxis 2D V.8.2 diperoleh nilai sebesar 1,1092.

2. Untuk solusi penanggulangan longsor lereng Sungai Lungun, ukuran dimensi perkuatan sheet pile yang diperoleh dari perhitungan yaitu menggunakan sheet pile beton tipe W-400 A 1000 dengan kedalaman 10 $\mathrm{m}$ ditambah dengan pengakuan angkur pada kedalaman $1 \mathrm{~m}$ dari permukaan tanah yang dikaitkan oleh tie rod baja $\varnothing 7 \mathrm{~cm}$ sepanjang $14 \mathrm{~m}$ kepada blok angkur beton dengan tinggi blok angkur 1,5 $\mathrm{m}$ dan tebal $5 \mathrm{~cm}$ yang tertanam $0,5 \mathrm{~m}$ dari permukaan tanah, maka menghasilkan nilai faktor keamanan lereng yang dihitung menggunakan program bantu Plaxis 2D V.8.2 sebesar 3,5814.

\section{Daftar Rujukan}

[1] Atibrata, Aryo Laksmana. 2020. "Perencanaan Dinding Penahan Tanah Jenis Corrugated Concrete Sheet Pile (CCSP) pada Pekerjaan Galian Apartemen Bengawan Malang”. Skripsi untuk derajat Sarjana Teknik, Universitas Muhammadiyah Surakarta.

[2] [BSN] Badan Standarisasi Nasional, 2017, Persyaratan Perancangan Geoteknik(SNI 8460:2017),BSN, Jakarta.

[3] Das, Braja M. dkk. 1985. Mekanika Tanah (Prinsip-prinsip Rekayasa Geoteknis) Jilid 1.Jakarta : Erlangga.

[4] Das, Braja M. dkk. 1994. Mekanika Tanah (Prinsip-prinsip Rekayasa Geoteknis) Jilid 2.Jakarta : Erlangga.

[5] Dwi Hardadi, Budisasongko. 2016. "Analisis Daya Dukung dan Penurunan Pondasi Rakit pada Kondisi Tanah Berlapis". Skripsi untuk derajat Sarjana Teknik Sipil, Universitas Katolik Parahyangan.

[6] Fahlevi, Farid. 2019. "Analisis Stabilitas Lereng dengan Perkuatan Sheet Pile Menggunakan Plaxis V.8 dan Metode Bishop (Studi Kasus : Pembangunan TPA Sipirok)”. Skripsi untuk derajat Sarjana Teknik Sipil, Universitas Sumatera Utara.

[7] Gabriella M. P., Violetta. 2014. Analisis Kestabilan Lereng dengan Metode Fellenius (Studi Kasus: Kawasan Citraland). Jurnal Sipil Statik Vol.2 No.1.

[8] Hardiyatmo, Hary Christady. 2015. Analisis dan Perancangan Fondasi II. Yogyakarta : Gadjah Mada University Press.

[9] Laboratorium Teknik Sipil UBT. 2018. Laporan Sondir \& Handbor Lokasi Sabanar Baru, Tanjung Selor. Tarakan : Laboratorium Teknik Sipil UBT.

10] Lembaga Penelitian dan Pengabdian Masyarakat UBT. 2018. Laporan Akhir Perencanaan Normalisasi Sungai Lungun Sabanar Baru Tanjung Selor. Tarakan : Lembaga Penelitian dan Pengabdian Masyarakat UBT.

11] Suharto. Perencana Sheet Pile Sungai Mahakam pada STA.0+100 - STA. 0+200 di Kecamatan Melak Kabupaten Kutai Kartanegara. Universitas 17 Agustus 1945 Samarinda. 